\title{
PENYEBARAN AGAMA ISLAM DI JAKARTA ABAD XVII - XIX
}

\author{
Oleh Lasmiyati \\ Balai Pelestarian Sejarah dan Nilai Tradisional Bandung \\ Jln. Cinambo No. 136 Ujungberung Bandung \\ Email: yanlas@bdg.centrin.net.id
}

\begin{abstract}
Abstrak
Penyebaran agama Islam di Jakarta dimulai sejak Fatahillah berhasil mengalahkan Portugis di Sunda Kelapa. Namun setelah Batavia diserang oleh Belanda, sebagian tokoh penyebar agama Islam berpindah dari Pelabuhan Pasar Ikan ke Kampung Melayu, mereka mendirikan masjid Al-Atiq. Sedangkan yang melarikan diri ke Jatinegara Kaum mereka mendirikan masjid As- Salafiah. Para tokoh penyebar Agama Islam di Jakarta, disamping melakukan syiar dakwah mereka juga mendirikan masjid.

Penyebaran Agama Islam pada abad XVII - XIX ditandai dengan berdirinya beberapa masjid kuno. Masjid-masjid tersebut disamping sebagai tempat sholat juga dijadikan sebagai tempat dakwah guna menyebarkan agama Islam.
\end{abstract}

Kata Kunci: Penyebaran agama Islam di Jakarta

Abstract

Spreading of Islam in Jakarta is started since Fatahillah successfully gives in Portugis in Sunda Kelapa. But after Batavia attacked by Dutch, some of Islam spreader figures makes a move from Pelabuhan Pasar Ikan to Kampung Melayu, they build mosque Al-Atiq. While running away to Jatinegara Kaum they to build mosque AsSalafiah. The Islamic Religion spreader figures in Jakarta, beside does syiar mission they also builds mosque.

Spreading of Islamic Religion at century XVII - XIX is marked with forming of some ancient mosques. The mosques beside as place of sholat also made as place of mission to propagate Islam.

Keywords: Spreading of Islam in Jakarta.

\section{A. Pendahuluan}

Sebelum agama Islam masuk ke Indonesia, masyarakat pada umumnya masih menganut agama Hindu. Masuknya agama Islam ke Indonesia pertama kali dibawa oleh para saudagar dari Arab. Kedatangan mereka di samping berdagang juga menyebarkan agama Islam. Para saudagar tersebut mendaratkan kapal dagangnya di wilayah pantai, baik di Jawa Timur, Jawa Tengah, maupun di Jawa Barat.

Awal masuk agama Islam Di Jawa Barat langsung disebarkan oleh Sunan Gunung Jati, putra dari Nhay Rarasantang. Nhay Rarasantang putera dari Raden Pamanahrasa atau Prabu Siliwangi yang menikah dengan Nyi Mas 
Subanglarang santri Syekh Quro dari Karawang. Di Usia 20 tahun, Sunan Gunung Jati bertekad ingin menyebarkan agama Islam dan menolak menjadi raja Mesir. Tahun $1470 \mathrm{M}$ ia tiba di Caruban menemui uwanya Pangeran Walangsungsang yang kemudian ia diangkat menjadi pendidik atau guru di pesantren. Sewaktu Syarif Hidayatullah (Sunan Gunung Jati) berkunjung ke Banten dan menyebarkan agama Islam, ia sempat mengislamkan Bupati Kawunganten dan pengikutnya. Di samping itu ia juga menikahi putrinya yang bernama Nyi Mas Kawunganten. Dari pernikahan tersebut mempunyai dua orang putra yaitu Sabakingkin (Sultan Hasanudin) dan Ratu Winaon. Oleh Sunan Gunung Jati, Banten dijadikan sebagai pusat penyebaran agama Islam yang dipercayakan kepada Sultan Hasanudin anaknya dengan wilayah persebarannya meliputi Banten Selatan, Jakarta, Bogor, dan Sukabumi. (Asmar, 1975: 97).

Jakarta yang saat ini menjadi ibukota negara, merupakan kota yang heterogen, dihuni oleh berbagai penganut keyakinan yang ada serta sukubangsa yang berbeda. Kedatangan mereka bertujuan untuk bekerja, berwiraswasta ataupun berwirausaha, mengingat di Indonesia ada beberapa agama yang telah disahkan sebagai agama resmi, seperti agama Islam, Katholik, Kristen, Protestan, Hindu, Budha, dan Konghuchu. Dari beberapa agama tersebut, Islam merupakan agama mayoritas termasuk di Jakarta.

Yang menjadi inti permasalahan:

1. Siapakah penyebar agama Islam di Jakarta?

2. Bagaimana proses penyebarannya?

Tujuan dari penelitian ini adalah untuk mencari jawaban atas permasalahan, yaitu: Untuk mengetahui sejak kapan masuknya agama Islam di Jakarta, Siapakah penyebar Agama Islam di Jakarta?
Ruang lingkup dibagi dalam dua bagian, yaitu ruang dan waktu. Pengertian ruang adalah penelitian yang lokasinya di DKI Jakarta, sedangkan pengertian waktu mengambil kurun waktu pada abad XVII-XIX.

Metode dalam penelitian ini menggunakan metode sejarah, dengan tahap-tahap meliputi heuristik yaitu tahap pengumpulan sumber. Tahap ini dilakukan sebagai studi pendahuluan berupa studi pustaka, yang dilakukan di beberapa perpustakaan, dan melakukan studi lapangan, yaitu terjun langsung ke lokasi penelitian dengan melihat peninggalan dari penyebaran Agama Islam di Jakarta. Setelah sumber terkumpul kemudian melakukan kritik baik ekstern maupun intern. Langkah berikutnya adalah interpretasi, yaitu untuk memperoleh penafsiran sehingga data telah menjadi fakta. Dan baru kemudian melakukan penulisan atau historiografi, yang bertujuan untuk merangkaikan fakta tersebut menjadi suatu kisah sejarah.

\section{B. Hasil dan Bahasan}

\section{a. Awal penyebaran Agama Islam di Jakarta}

Mengenai awal penyebaran agama Islam di Jakarta, ada yang berpendapat bahwa masuknya agama Islam ke Jakarta pada abad XII. Hal itu ditandai dengan datangnya para pedagang muslim yang berasal dari Gujarat, Persia, semenanjung Arabia. Para pedagang tersebut menelusuri alur perdagangan sampai ke Cina. (www.Kpsbihistoria.blogdrive.com).

Namun menurut Ridwan Saidi, awal penyebaran agama Islam di Jakarta dapat diruntut dari berdirinya Pesantren Quro di Karawang. Syekh Quro adalah Syekh Hasanudin seorang warga Kamboja, ia datang ke tanah Jawa untuk berdakwah, ia mendaratkan kapalnya di Karawang, 
dan membangun pesantren. Selama memimpin pesantren tersebut ia mempunyai banyak santri, salah satunya bernama Nyai Subang Larang yang kemudian dipersunting oleh Prabu Siliwangi. (softoh-jamah-blogspot.com). Disamping itu Syekh Quro juga membangun masjid. Menurut Ridwan Saidi, semenjak Syekh Quro mendirikan pesantren, penyebaran Islam di kalangan penduduk mengalami perkembangan. (Saidi, 2002: 109).

\section{b. Proses Penyebaran Agama Islam di Jakarta}

Pada masa-masa penyampaian agama Islam ke wilayah Jakarta, tidak semata berjalan mulus, namun mengalami proses kesulitan, rintangan dan hambatan. Hambatan tersebut muncul berupa tantangan yang datang dari bangsawan Pajajaran dan para resi. Tantangan pertama datang dari para dato, bangsawan di masa Surosowan, mereka beranggapan bahwa masyarakat Pajajaran telah mempunyai agama lokal atau yang sering diberi nama sunda wiwitan.

Rintangan kedua, dalam proses penyebaran agama Islam di Jakarta terkadang dihadapinya dengan perlawanan dari dato-dato yang menganut tarekat, sehingga pada waktu itupun dikenal dengan istilah elmu panemu jampe pamake, sehingga para resi pun banyak yang menganut agama Islam. Prabu Surawisesa kemudian masuk Islam dan menikah dengan Kiranawati dan sesudah masuk Islam Surawisesapun ngahiyang. Ia dimakamkan di Sodong, di luar komplek Jatinegara. Ajaran tarekat datodato tersebut akhirnya menjadi isi dan aliran main pukulan syahbandar yang dibangun oleh Wa Item. Wa Item adalah syahbandar pelabuhan Sunda yang gugur ketika berhadapan dengan Faletehan (softoh-jamah-blogspot.com).
Ketika warga Betawi mulai memeluk agama Islam, hambatan masih juga dialami, yaitu dari para pendeta. Para warga yang telah mengikuti jejak Kian Santang dinilai melakukan penyimpangan yang menurut istilah waktu itu adalah langgara. Sehingga tempat sembahyang umat Islam waktu itu diberi nama langgar, yang artinya adalah mushola.

Dalam proses penyebaran agama Islam di Betawi (Jakarta), terdapat tujuh wali Betawi, antara lain Pangeran Darmakumala dan Kumpi Datuk yang dimakamkan berdekatan di tepi kali Ciliwung, dekat kelapa dua Jakarta Timur. Kemudian Habib Sawangan yang makamnya berada di depan pesantren AlHamidiyah, Depok. Pangeran Papak yang dimakamkan di jalan Perintis Kemerdekaan Jakarta Utara (http://kian-santang-blogspot.com). Para wali menyampaikannya dengan media dakwah dan dilanjutkan dengan pembangunan masjid. Dalam penyebaran agama Islam menurut Slamet Muljana, dimulai ketika Fatahilah menetap di Banten. Fatahilah pernah mengunjungi Sunda Kelapa sambil menyiarkan agama Islam (Slamet Muljana, 1980: 58), masuknya agama Islam di Jakarta dimulai dari kemenangan Fatahillah ketika melakukan penyerbuan ke Sunda Kelapa. Ketika Fatahillah mendapat kemenangan sewaktu menaklukkan bangsa Portugis di Sunda Kelapa, ia diangkat sebagai penguasa di Sunda kelapa. Ketika itu Fatahillah harus kembali ke Demak, jabatan sebagai penguasa di Jayakarta diserahkan kepada menantu Hasanudin yaitu Tubagus Angke. Jabatan Tubagus Angke sebagai bupati di Jayakarta, kemudian diserahkan kepada putranya yang bernama Pangeran Jayakarta Wijayakrama. Masa pemerintahan Wijayakrama berakhir tahun 1619 karena pada tahun tersebut ia dipanggil oleh Sultan Banten Abdul 
Mufakhir Mahmud Abdul Kadir. Ketika Jayakarta di bawah penguasa bupati Jayakarta Wijayakrama, Jayakarta telah memeluk Agama Islam. Hal ini diperkirakan karena ia adalah cucu Sultan Hasanudian yang telah memeluk agama Islam, sehingga secara tidak langsung putra Ratu Winaon tersebut otomatis telah masuk Islam. Selama menjabat sebagai penguasa di Jayakarta, Pangeran Jayakarta pun memiliki pola kota seperti kota Islam lainnya di Jawa. Untuk kegiatan keagamaan, masjid berada di tengah kota dan dijadikan tempat syiar agama Islam (M. Dien Majid, 1995: 84). Di saat Pangeran Jayakarta meninggal dunia (1619), Jayakarta jatuh ke tangan VOC dan sebagian tokoh penyebar agama Islam pun berpindah dari Pelabuhan Pasar Ikan ke Kampung Melayu. Sebagian masyarakat melarikan diri ke arah Kampung Melayu, mereka mendirikan masjid Al-Atiq, dan sebagian lagi ke kampung Jatinegara Kaum. Mereka mendirikan masjid yang diberi nama, Masjid As-Salafiah. Nama Jatinegara kaum tersebut diambil karena daerah tersebut dihuni oleh para kaum yaitu sebutan untuk penghulu agama (Pemda DKI Jakarta, 2004: 37)

Namun ada sebuah pendapat yang mengatakan bahwa masjid As-Salafiah, didirikan oleh Pangeran Jaketra, yaitu anak dari Pangeran Jayakarta Wijayakrama. Kedatangan Pangeran Jaketra ke Jatinegara Kaum tersebut, akibat kekalahan yang diderita ketika menghadapi Belanda/VOC. Selain Pangeran Jaketra, sebagai penyebar Agama Islam, antara lain Pangeran Sugiri dan Pangeran Sake. Kedatangan mereka ke Jakarta karena tidak kuat melihat pergerakan yang terjadi di Banten. Tokoh ulama di DKI Jakarta yang hidup pada abad XVII, antara lain Datuk Wan dan Datuk Makhtum. Mereka diduga merupakan pendiri Masjid Sunda Kelapa, yang pindah ke Melayu. Kepindahan tersebut akibat tekanan dari Belanda.

\section{c. Masjid sebagai tempat penyebaran Agama Islam}

Para penyebar agama Islam, tidak hanya menerapkan syiar dakwah, akan tetapi juga membangun masjid. Dalam catatan pendeta Thornton yang ditulis oleh Heuken SJ, bahwa pada tahun 1678 di Jakarta terdapat tiga masjid. Ketiganya berkaitan dengan adanya orang Moor yang menyebarkan agama Islam di abad XVII. Mereka mendirikan masjid di pertengahan abad ke XVIII dengan nama masjid Luar Batang (1738), Pekojan (1760), dan Kebon Jeruk (1786). Kemudian pada abad XIX, penyebaran agama Islam di Jakarta diwarnai dengan datangnya orang dari Arab. Kedatangan mereka ikut mewarnai dalam penyebaran Agama Islam. Orang-orang Arab tersebut ada yang menetap di Betawi mulai abad XVII dan XVIII mereka berasal dari Gujarat.

\section{1). Masjid yang dibangun pada abad XVII}

\section{a). Masjid Al-Ansor}

Masjid ini berlokasi di Jalan Pengukiran II kelurahan Pekojan Glodok Jakarta Kota, yang didirikan pada tahun 1648 atau abad XVII (http://kpsbihistoria.blogdrive.com). Masjid ini merupakan masjid tertua yang masih berdiri, yang dibangun oleh bangsa Moor yaitu istilah untuk pedagang Islam dari Koja (India). Pada awalnya masjid ini hanya berupa mushola/langgar.

b). Mesjid al-Alam Cilincing

Masjid ini didirikan oleh Sunan Gunung Jati pada abad ke XVI, dan berkaitan dengan penyerbuan Fatahillah ke Sundakelapa. Disamping sebagai tempat sholat, masjid ini juga tempat musyawarah ketika pasukan Mataram akan menyerang Batavia. 


\section{c). Masjid Al Alam di Marunda}

Masjid yang terletak di Kampung Marunda Besar ini masuk dalam Kecamatan Cilincing, Jakarta Utara. Masjid ini didirikan oleh Fatahillah ketika ia dan pasukannya menyerang bangsa Portugis. Masjid ini dijadikan sebagai tempat pengatur siasat perang yang dilakukan oleh pasukan Mataram ketika melakukan penyerbuan ke Batavia.

2). Masjid yang dibangun pada abad XVIII:

\section{a). Masjid al-Mansyur}

Masjid ini berlokasi di Jalan Sawah Lio II No. 33 yang ada di Kampung Jembatan Lima, dibangun pada tahun 1717 (abad XVIII) (Heuken SJ, 2003: 43).

\section{b). Masjid Luar Batang}

Masjid ini terletak di sebelah utara tembok kota lama. Pada pertengahan abad ke XVII, masjid tersebut diurug, dan baru boleh dihuni sejak tahun 1730 oleh orang Jawa dari Cirebon. Di dalam masjid Luar Batang terdapat sebuah batu yang bertuliskan: al' Habib Husein b. Abukakar b. Abdullah al-Alaydrus yang telah wafat pada hari Kamis 27 Puasa 1169 berkebetulan 24 Juni 1756.

\section{c). Masjid Jamian-Nawier atau lebih dikenal sebagai Masjid Jami' Pekojan di Batavia, atau Jakarta tempo dulu}

Masjid yang terletak di Jalan Pekojan No. 79, masuk dalam Kecamatan Tambora, Jakarta Barat. Masjid ini didirikan oleh Pangeran Dahlan, dikenal sebagai ulama yang sangat disegani pada masanya. Masjid ini dikenal sebagai tempat berkumpulnya para pejuang, yang dikomandani oleh Dahlan.

\section{d). Masjid Angke Al-Anwar}

Sekilas masjid ini hanya merupakan sebuah surau kampung, namun termasuk dalam katagori benda cagar budaya, yang dilindungi oleh
Undang-Undang Monumen Ordonantie stbl No. 238 tahun 1931, dan diperkuat oleh SK Gubernur DKI Jakarta tanggal 10 Januari 1972. Masjid Angke Al Anwar, didirikan tanggal 2 April 1761 atau Hari Kamis 26 Sya'ban 1174, tidak lepas dari peran serta Fatahillah dan Tubagus Angke.

\section{e). Masjid Kebon Jeruk}

Masjid ini dibangun pada abad XVIII dan berhubungan dengan orangorang Tionghoa yang menganut agama Islam.

\section{f). Masjid Krukut}

Masjid ini dibangun pada tahun 1785, dan pernah dipugar pada abad XIX dan XX.

\section{g). Masjid Tambora}

Masjid yang dibangun pada pertengahan abad ke XVIII ini adalah masjid Tambora. Masjid ini terletak di Jalan Tambora IV yang dahulu disebut Jalan Blandongan. Menurut Heuken SJ, masjid ini dibangun oleh Tionghoa Muslim (ibid hal. 76).

h). Masjid As-Salafiah di Jatinegara Kaum, Pulogadung Jakarta Timur.

Ketika Jan Pieter Zoon Coen, membumihanguskan keraton, masjid, dan rumah-rumah penduduk, Pangeran Jaketra dan pengikutnya hijrah ke Jatinegara Kaum, ia membangun sebuah masjid As-Salafiah. Daerah tersebut mengambil nama kaum, karena dihuni oleh kaum-kaum ningrat terutama dari kasultanan Banten. Pangeran Jaketra menjadikan masjid sebagai tempat bergerilya dan menyusun kekuatan untuk melawan Belanda.

\section{3). Masjid yang dibangun pada abad XIX}

\section{a). Mesjid at-Taibin}

Masjid ini berlokasi di Jalan Kaki Lie, didirikan pada tahun 1815 , dengan 
gaya bangunan campuran antara Eropa dan Indonesia. Masjid ini pernah menjadi markas Siliwangi. penyimpanan logistik, dan tempat para ulama memberikan semangat kepada pejuang dalam melawan Belanda.

\section{b). Langgar Tinggi}

Masjid yang dibangun pada abad XIX ini terletak di Kelurahan Pekojan. Langgar ini berlantai dua, lantai atas digunakan sebagai masjid, dan lantai bawah digunakan sebagai tempat tinggal pengurus masjid. Langgar tinggi ini terdapat unsur-unsur arsitektur Eropa (yaitu pada pilar klasisisme, kemudian Tiongkok dan arsitektur Jawa. Masjid Langgar Tinggi dibangun pada tahun 1829 menyatu dengan Kali Angke. Bila para jamaah yang melaksanakan sholat fardlu di masjid tersebut dapat langsung mengambil air wudlu di kali Angke. (www.strada.or.id)

\section{c). Masjid Nurushshabah}

Masjid yang didirikan 1839 ini dahulunya disebut Masjid Pos Bidaracina yang pendirinya bernama Imam Muhamad. Ia memperoleh tanah dari kumpeni.

\section{d). Masjid Al-Atiq}

Masjid yang berlokasi di Jalan Masjid I Kampung Melayu Besar Jakarta Selatan, merupakan peninggalan Sultan Sultan Hasanudin. Hal itu dilihat dari arsitekturnya, bahwa masjid ini berdiri pada abad XVI. Masjid ini pernah menjadi tempat persembunyian si Pitung ketika melarikan diri dari penjara Meester Cornelis (Jatinegara), pada tahun 1890. Ia jagoan Betawi, dan pembela rakyat kecil. Atas saran pengurus masjid tersebut, si Pitung diperbolehkan bersembunyi di masjid tersebut dalam jangka waktu yang tidak ditentukan.

\section{e). Masjid Jami al Makmur}

Masjid Al Makmur berlokasi di tanah Abang Jakarta. Masjid tersebut dahulunya hanya mushola yang dibangun pada tahun $1704 \mathrm{M}$ oleh KH Muhammad Asyuro. Ia merupakan bagian dari laskar Mataram yang kalah perang melawan Belanda, ketika peristiwa penyerbuan pasukan Sultan Agung ke Batavia (Republika, 15 Desember 2006).

\section{d. Perkembangan Agama Islam Abad XIX}

Pada pertengahan abad ke XIX, proses penyebaran agama Islam di Jakarta ditandai dengan banyaknya orang-orang Betawi yang menunaikan ibadah haji ke Mekah. Di Mekah mereka banyak bertemu dengan masyarakat Indonesia lainnya baik dari Banten, Jawa, Thailand/Phanai, dan Minangkau. Dibandingkan dengan masyarakat dari berbagai daerah tersebut, orang-orang Betawi yang menunaikan ibadah haji termasuk yang paling banyak. Selama mereka berada di Mekah mereka memakai nama-nama daerah mereka. Misalnya ulama yang berasal dari Betawi menggunakan nama belakang dengan kata Al Batawi, Begitu pula ulama yang berasal dari Banten menggunakan nama dibelakangnya $\mathrm{Al}$ Bantani, yang dari Jawa Al Jawani, dan sebagainya. Dari beberapa ulama tersebut ulama dari Betawi yang paling terkenal adalah Syekh Junaid al-Batawi asal kampung Pekojan (Betawi). Di kala naik haji pada abad ke XVIII, ia pernah dipercaya sebagai imam masjid di Masjidil Haram oleh penguasa Hejaz. Disamping itu ia juga dipercaya untuk mengajar di serambi masjid tersebut. Syekh Junaid Al Batawi mempunyai empat orang anak yang terdiri dari dua laki-laki dan dua orang perempuan. Kedua anak laki-laki tersebut masing-masing bernama Said dan Sa'ad, mereka meneruskan kiprah orang tuanya sebagai penyebar agama Islam di Betawi. Syekh Junaid Al Batawi 
mempunyai banyak murid yang akhirnya menyebar ke berbagai daerah di Nusantara, mereka diantaranya adalah Syekh Nawawi Banten. Syekh Junaid Al Batawi lama-lama dikenal di kalangan luas sehingga banyak sekali muridmuridnya yang menggunakan nama $\mathrm{Al}$ Batawi.

Setelah Syekh Junaid meninggal, peran masjid diteruskan oleh ulamaulama penerusnya yang dahulu menjadi muridnya dan tentu saja bersama-sama dengan kedua putranya. Dari murid dan putranya tersebut akhirnya berhasil menanamkan identitas Islami pada suku bangsa Betawi. Sarana yang digunakan adalah masjid dan langgar/mushola, dan langgar yang paling terkenal adalah Langgar Tinggi Pekojan yang didirikan 1828. (Ridwan Saidi, 2002: 143).

\section{Penutup}

Penyebaran Islam di Jakarta terjadi antara abad XVII-XIX. Dalam mengislamkan Jakarta, Sunan Gunung Jati memiliki peranan penting. Ketika Fatahillah sebagai bupati di Jayakarta, pernah mendapat bantuan pasukan dari Sunan Gunung Jati ketika mengalahkan Kerajaan Sunda. Dengan kalahnya Kerajaan Sunda oleh Fatahillah, secara otomatis wilayah Sunda kelapa menganut agama Islam. Apalagi pasukan Fatahilah yang mendapat dukungan dari Demak. Dengan kemenangan Fatahillah tersebut secara tidak langsung agama Islam mulai berkembang di Jakarta. Fatahillah kemudian digantikan oleh putranya Tubagus Angke. Pada masa itulah pasukan Belanda datang ke Indonesia di bawah pimpinan Jan Pieter Zoon Coen. Selama Tubagus Angke menjabat sebagai bupati di Jayakarta, tidak ditemukan bukti-bukti mengenai penyebaran Agama Islam. Dari Tubagus Angke digantikan oleh putranya yaitu Pangeran Wijayakrama, atau dikenal dengan nama Pangeran Jayakarta
Wijayakrama. Pangeran Wijayakrama pun harus berhadapan dengan Belanda karena Jan Pieter Zoon Coen memorakporandakan kota Jayakarta. Ia membumihanguskan rumah-rumah penduduk, masjid, dan keraton. Pangeran Jayakarta mengalami kekalahan. Dengan kekalahan tersebut, Belanda menguasai Jayakarta hingga mengganti nama menjadi Batavia. Dengan kalahnya Pangeran Wijakarama, banyak sisa-sisa pengikutnya masih melakukan perlawanan, namun kalah karena sifat pertempuran tersebut berskala kecil. Pangeran Jaketra putra Pangeran Wijakrama merasakan bahwa keraton kondisinya sudah rusak, sehingga ia beserta pengikutnya melarikan diri ke pinggiran, diantaranya ke Jatinegara kaum dekat Pulo Gadung Jakarta Timur. Di sana mereka menetap dan mendirikan masjid. Masjid-masjid tua yang ada di Jakarta, pada umumnya dibangun pada abad XVII sampai dengan abad XIX. Di samping sebagai tempat sholat guna mendekatkan diri kepada Sang Pencipta, juga dijadikan sebagai tempat musyawarah, membakar semangat untuk mengusir penjajah, dan tempat menyebarkan agama Islam. Bahkan di masjid pula si Pitung sang pejuang bersembunyi tatkala ia dikejar oleh tentara Belanda.

Dahulu, masjid-masjid di Jakarta bukan hanya sebagai tempat dakwah dalam menyebarkan agama Islam, melainkan juga sebagai tempat musyawarah dan membangkitkan semangat perjuangan. Diharapkan masjid-masjid yang dibangun pada abad XVII-XIX dilestarikan sebagai saksi sejarah.

\section{DAFTAR PUSTAKA}

Asmar, Teguh et al. 1975.

Sejarah Jawa Barat, dari masa Pra Sejarah Hingga Masa Penyebaran Agama Islam. Bandung: Proyek Penunjang Pe- 
ningkatan Kebudayaan Nasional Propinsi Jawa Barat.

2004.

Lintasan Sejarah Jakarta. Jakarta: Dinas Kebudayaan dan Permuseuman Propinsi DKI Jakarta.

Heuken SJ. 2003.

Masjid-masjid Tua di Jakarta. Jakarta: Cipta Loka Caraka.

Muljana, Slamet. 1980.

Dari Holotan ke Jayakarta, Jakarta: Idayu.

Republika, 15 Desember 2006

Saidi, H. Ridwan. 2002.
Babad Tanah Betawi, Jakarta: Gria Media Prima.

Shahab, Alwi. 2006.

"Masjid-masjid Tua di Jakarta", Republika, 23 Juni 2006.

Soemardjo, RH Unang. 1983.

Meninjau Sepintas Panggung Sejarah Pemerintahan Kerajaan Cerbon, 1479-1809. Bandung: Tarsito.

\section{Sumber Elektronik}

http://www.jakarta.go.id/sejarah pemerintahan.html.

http://kpsbbi-historia.blogdrive.com http:// www.strada.or.id http:// kpsbi-historia.blogspot.com http://kian-santang-blogspot.com. 